\title{
Kearifan Lokal dalam Perilaku Sosial Remaja di Desa Waimiting Kabupaten Buru
}

\author{
Susiati $^{1^{*}}$, Andi Masniati², Risman lye ${ }^{3}$, La Husni Buton ${ }^{4}$ \\ 1,2,3 Fakultas Sastra, Universitas Iqra Buru, Indonesia \\ ${ }^{4} \mathrm{FAl}$, Universitas lqra Buru, Indonesia \\ "Korespondensi: susiatiuniabu@gmail.com
}

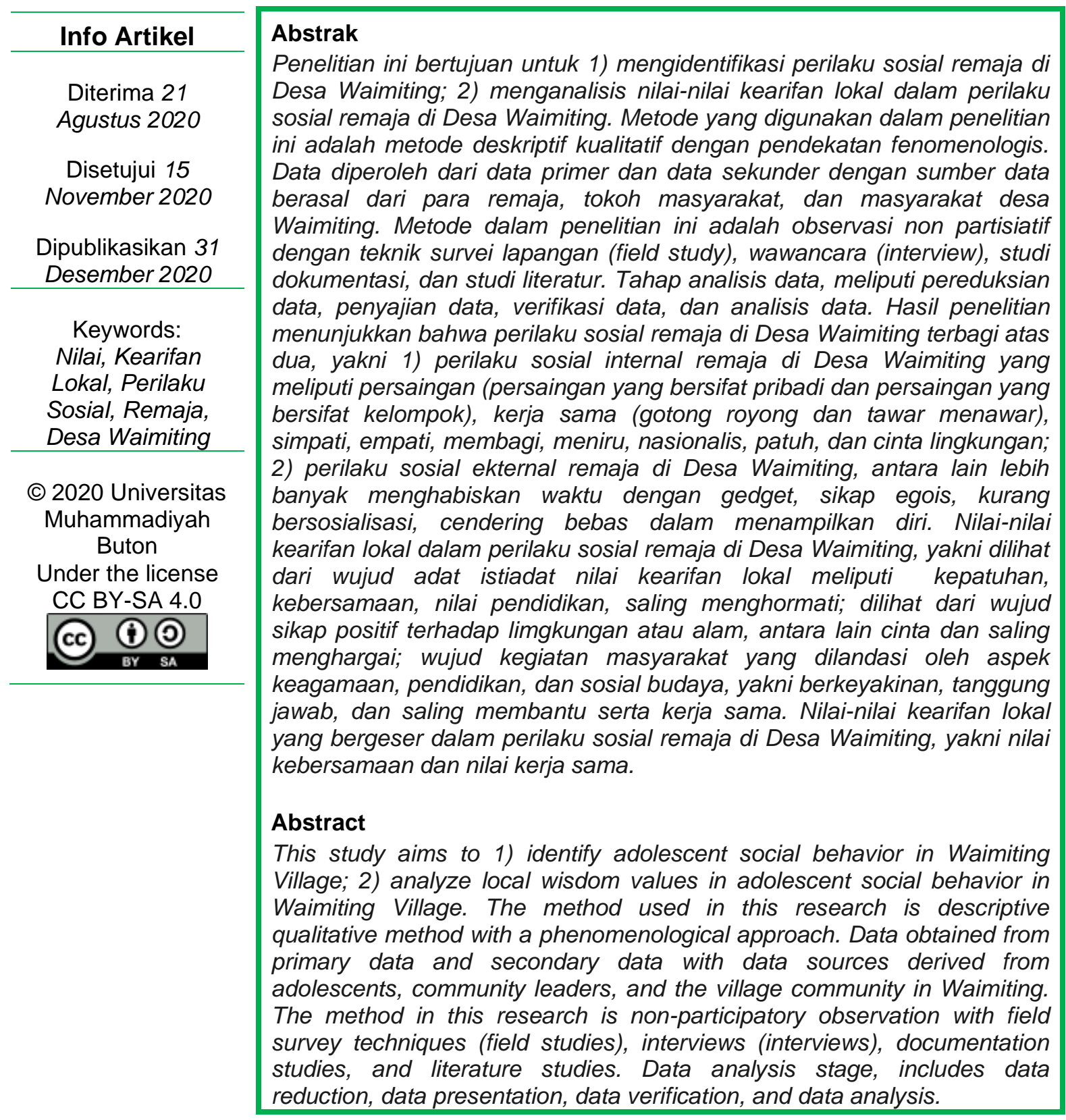




The results showed that the social behavior of adolescents in Waimiting
Village was divided into two, namely 1) internal social behavior of
adolescents in Waimiting Village which included competition (personal
competition and group competition), cooperation (mutual cooperation and
bargaining), sympathy, empathy, share, imitate, nationalist, obedient, and
love the environment; 2) external social behavior of adolescents in
Waimiting Village, among others, spending more time with gedget
(mobile), selfish attitude, less socializing, tend to be free in presenting
themselves. The values of local wisdom in adolescent social behavior in
Waimiting Village, which are seen from the customs of the values of local
wisdom include obedience, togetherness, the value of education, mutual
respect; seen from the form of a positive attitude towards the environment
or nature, including love and mutual respect; seen from the form of
community activities that are based on religious, educational, and socio-
cultural aspects, namely belief, responsibility, and mutual assistance and
cooperation. The values of local wisdom shifted in the social behavior of
adolescents in Waimiting Village, namely the value of togetherness and
the value of cooperation.

\section{Pendahuluan}

Kearifan lokal termanifestasi dalam kehidupan manusia mulai dari adanya peradaban di dunia. Kearifan lokal tercermin melalui sikap dan perilaku manusia baik perilaku manusia kepada manusia maupun perilaku menusia terhadap lingkungannya.

Bagi masyarakat wujud kearifan lokal sudah menjadi tradisi yang melekat kuat dalam kehidupan. Terjadinya perbedaan karakter dan intensitas hubungan sosial budaya tidak menjadikan masyarakat menjauhi tradisi karena seyogyanya masyarakat tersebut sudah terikat dalam persamaan visi dalam menciptakan kehidupan yang bermartabat. Kearifan lokal menjadikan anggota masyarakat menjunjung tinggi nilai dan norma sosial ketika dalam proses interaksi.

Kearifan lokal berasal dari dua kata, yakni kearifan dan lokal. Tarakanita dkk. (2013) mengatakan bahwa kearifan lokal merupakan kemampuan seseorang dalam menggunakan akal pikirannya ketika bertindak atau bersikap sebagai suatu wujud hasil penilaian terhadap suatu objek atau peristiwa yang terjadi (hal. 45). Lokal diartikan sebagai ruang interaksi yang terbatas dengan sistem nilai yang terbatas pula.

Kearifan lokal adalah segala bentuk kebijaksanaan berdasar pada nilai dan norma kebaikan yang diterapkan, dipercaya, dan dijaga keberlangsungannya dalam waktu yang cukup lama (secara turun temurun) oleh sekelompok orang dalam lingkungan, wilayah, atau daerah tertentu yang menjadi tempat tinggal mereka. Kearifan lokal dapat terwujud dalam beberapa bentuk, yakni rasa nasionalisme terhadap tanah kelahiran, bentuk sifat, sikap, tabiat masyarakat yang tetap melekat meskipun sudah lama diperantauan atau berbaur dengan masyarakat di daerah lain, falsafah yang sudah mendarah daging dan telah melekat meski telah lama hidup diperantauan, pola pikir masyarakat yang mengandung nilai, adab, tata krama, berbudi pekerti yang baik, dan keinginan besar untuk tetap menjalankan adat dan tradisi yang telah melekat secara turun temurun. Singsomboon (2014) mengatakan bahwa kearifan lokal adalah suatu 
pengetahuan tentang kedaerahan yang didapat melalui pengalaman dan permulaan hidup yang telah diwariskan dari generasi ke generasi (hal. 67).

Wujud kearifan lokal masyarakat Waimiting terakumulasi dalam nilai-nilai yang sudah mentradisi secara tradisional seperti kebaikan, kedamaian, kesejahteraan, rasa nasionalisme, kebersamaan, ketenteraman, saling menghargai, serasa sepenanggungan, dan punya falsafah hidup. Nilai-nilai tersebut bagi masyarakat Waimiting merupakan pedoman dalam sistem perilaku masyarakat baik antarindividu maupun antarkelompok. Hilmi (2015) menyatakan bahwa nilai merupakan suatu konsep yang menjadi ciri khas dari individu atau kelompok masyarakat terhadap mode, tindakan, dan maksud (hal. 89).

Dunia intersubjektif ikut andil dalam menentukan kehidupan anak-anak remaja dalam lingkungan masyarakat. Artinya, tabiat, sifat, dan perilaku anak-anak remaja dipengaruhi oleh budaya dalam lingkungannya. Budaya tersebut termanifestasi dalam mengelola dan memengaruhi pembawaan sifat dan perilaku para remaja. Hal ini sejalan dengan pendapat Ritzer (2014), dunia intersubjektif menciptakan suatu realitas sosial yang dipaksa oleh struktur budaya dan lingkungan sosial ciptaan leluhur mereka sebelumnya (hal. 35). Oleh karena itu, pada diri remaja diperlukan sosialisasi dan internalisasi nilai-nilai semenjak mereka masih kecil. Ritzer (2014) mengatakan bahwa syarat dan fungsi bagi terpeliharanya integritas pola nilai di dalam sistem adalah proses internalisasi dan sosialisasi (hal. 86).

Hal yang menjadi dasar pertimbangan sehingga kearifan lokal perilaku sosial remaja di Desa Waimiting menjadi objek penelitian, yaitu menyangkut sikap baik (sikap positif) dan sikap yang kurang baik (sikap negatif). Sikap positif, misalnya sikap menjunjung tinggi adat atau tradisi pantang larang yang berlaku, sebagian besar masih memegang ketentuan atau aturan yang berlaku, tidak membawa budaya luar daerah ke dalam daerah mereka (sikap nasionalisme). Sikap negatif, seperti acuh tak acuh terhadap berbagai peringatan dan teguran yang diberikan kepada para remaja, baik oleh orangtua, masyarakat, ataupun tokoh masyarakat. Sedikit demi sedikit para remaja terpengaruh oleh pergaulan remaja dari luar daerah. Pemertahanan dan pergeseran nilai-nilai kearifan lokal pada para remaja di Desa Waimiting dilakukan karena semata-mata ingin memperkenalkan jati dirinya dalam pergaulan dan ingin mencari kebebasan.

Adapun penelitian terdahulu yang membahas tentang nilai-nilai kearifan lokal dalam perilaku sosial remaja, yakni 1) Hilmi (2015) tentang Nilai-nilai Kearifan Lokal Dalam Perilaku Sosial Anak-anak Remaja di Desa Sepit Kecamatan Keruak Kabupaten Lombok Timur. Adapun masalah yang diangkat oleh Hilmi adalah mendeskripsikan perilaku sosial anak-anak remaja, nilai-nilai kearifan lokal yang bergeser dalam perilaku anak-anak remaja serta mendeskripsikan pergeseran nilai-nilai kearifan lokal yang membangun struktur nilai baru yang berpengaruh terhadap perilaku sosial anak-anak remaja. Hasil penelitian membuktikan bahwa nilai-nilai kearifan lokal tidak lagi digunakan sebagai pedoman dalam perilaku sosial anak-anak remaja, mereka lebih cenderung menggunakan nilai-nilai baru yang mereka bangun sendiri. Nilai-nilai kearifan lokal menjadi bergeser sebagai akibat dari pengaruh perkembangan teknologi informasi, rendahnya latar belakang pendidikannya, pergaulan yang mereka jalani, dan faktor keluarga yang memberikan peluang terjadinya pelanggaran terhadap nilai. Di samping itu pula peran dan fungsi lembaga sosial seolah-olah 
tidak ada dalam mempertahankan atau dalam mewariskan nilai-nilai kearifan lokal. Anak-anak remaja lebih memilih menggunakan nilai baru yang dianggapnya memberikan kebebasan dan kepuasan, karena nilai-nilai kearifan lokal dianggapnya mengikat, tradisional, dan ketinggalan zaman. Persamaan penelitian ini dengan peneltian Hilmi (2015), yakni sama-sama mengangkat masalah yang sama tetapi perbedaannya adalah pada lokasi dengan budaya serta pandangan masyarakat yang berbeda.

Berdasarkan deskripsi di atas, penelitian ini bertujuan untuk mengidentifikasi perilaku sosial remaja di Desa Waimiting dan menganalisis nilai-nilai kearifan lokal dalam perilaku sosial remaja di Desa Waimiting.

\section{Landasan Teori}

\subsection{Nilai}

Nilai merupakan tonggak atau patokan kearifan lokal di masyarakat. Nilainilai budaya dalam masyarakat dapat menjadi norma, prinsip hidup, pedoman hidup dalam suatu masyarakat yang diturunkan dari generasi ke generasi (Mansyur, 2016: 331-332). Nilai telah lama berevolusi dalam lingkungan masyarakat dan sudah beberapa kali mengalami masa periode dari generasi ke generasi (Hasbullah, 2012: 45). Kearifan lokal hampir terlupakan oleh masyarakat akibat adanya perubahan sosial saat ini dan hampir juga terlupakan oleh sejarah. Pada zaman nenek moyang, kearifan lokal terbentuk oleh budaya, adat, dan tradisi masyarakat sehingga hal tersebut dikatakan sebagai produk budaya.

Susiati (2019) mengatakan bahwa manusia adalah makhluk sosial yang perkembangan jiwanya tidak ditentukan sejak lahir tetapi dibentuk oleh lingkungannya. Lingkungan manusia itulah yang disebut kebudayaan (hal. 117).

\subsection{Kearifan Lokal}

Kearifan lokal merupakan bentuk perilaku manusia dalam menghargai segala ketentuan yang telah menjadi tuntunan hidup dari para leluhur. Kearifan lokal terwujud dalam perilaku positif manusia dalam hubungannya dengan manusia, alam dan lingkungan sekitar yang bersumber dari nilai-nilai dan norma-norma seperti nilai agama, adat istiadat, budaya setempat, serta petuah atau nasihat nenek moyang yang terbentuk secara alamiah dalam suatu komunitas.

Aslan (2017) menyatakan bahwa kearifan lokal merupakan kecerdasan yang dimiliki oleh sekelompok suku atau etnis tertentu yang didapat dari pengalaman dalam lingkungan masyarakat (hal. 67). Sama halnya dengan Sukmayadi (2018) yang mengatakan bahwa kearifan lokal merupakan gagasan dan ide lokal atau gagasan masyarakat setempat secara bijaksana, bernilai baik, dan penuh kearifan yang tertanam dan diikuti oleh anggota masyarakatnya (hal. 70).

Kearifan lokal mengandung kebaikan bagi individu maupun kelompok masyarakat sendiri kemudian dipakai dan mentradisi serta melekat kuat dalam sikap dan perilaku masyarakat sehari-hari (Abdulsyani, 2015: 90). Kearifan lokal yang dimaksud, yaitu nilai-nilai budaya, masyarakat, hukum adat, dan kepercayaan yang mereka anut.

Ridwan (2007) menyatakan bahwa kearifan lokal (local wisdom) dapat dipahami dan diartikan sebagai usaha menulis dengan menggunakan akal budi 
(kognisi) untuk bertindak dan bersikap terhadap sesuatu obyek atau peristiwa yang terjadi dalam ruang tertentu (hal. 78).

Mansyur (2018) menjelaskan bahwa kearifan lokal adalah sebuah "konsep yang terkait dengan kebijaksanaan, pemahaman, ataupun kepandaian masyarakat di suatu tempat yang digunakan untuk mengatasi pelbagai permasalahan hidup yang mereka hadapi"(hal.58).

Menurut Hilmi (dalam Susiati, 2018), terapat beberapa tipe kearifan lokal, yaitu 1) kearifan lokal yang berhubungan dengan pengobatan; 2) kearifan lokal dalam hubungannya dengan sistem produksi; 3) kearifan lokal dalam hubungannya dengan makanan; 4) kearifan lokal dalam hubungannya dengan sesama manusia; 5) kearifan lokal dalam hubungannya dengan pakaian; dan 6) kearifan lokal dalam hubungannya dengan perumahan (hal. 299).

Fungsi kearifan lokal, yaitu 1) untuk pengembangan sumber daya manusia (SDM); 2) untuk pengembangan kebudayaan dan ilmu pengetahuan; 3) untuk konservasi dan pelestarian alam; 4) sebagai petuah, sastra, dan pantangan atau larangan; 5) bermakna sosial; 6) bermakna etika, sikap, adab, dan moral (Hilmi, 2015: 86).

\subsection{Perilaku Sosial}

Perilaku merupakan aktifitas atau tindakan manusia yang mencakup segala hal, seperti berbicara, menangis, berjalan, tertawa, menulis, bekerja, membaca, mendengar, dan kuliah. Martin dan Joseph (2015) mengemukakan bahwa dimensi perilaku adalah karakteristik perilaku yang dapat diukur. Adapun tiga dimensi perilaku yang dimaksud adalah 1) frekuensi merupakan suatu sikap atau perilaku yang merujuk pada jumlah tindakan atau aktifitas yang muncul pada periode waktu tertentu; 2) durasi, yaitu suatu perilaku atau tingkah laku yang merujuk pada panjangnya waktu yang dibutuhkan ketika perilaku melakukan aktifitas atau aksinya; 3) kekuatan atau intensitas maksudnya adalah suatu perilaku yang merujuk pada upaya fisik atau energi yang dilibatkan untuk melakukan suatu tindakan (hal. 125).

Aslan (2017), perilaku terbagi menjadi dua jenis, yaitu 1) perilaku alami (innate behavior), yakni tingkah laku atau perilaku yang dibawa sejak organisme dilahirkan, yakni berupa insting-insting dan refleks-refleks; 2) perilaku operan, yaitu perilaku yang dipelajari, dibentuk, dan dapat dikendalikan serta diatur oleh pusat kesadaran atau otak (hal. 56).

\subsection{Bentuk Perilaku Sosial}

Sukmayadi (2018) mengatakan bahwa perilaku sosial dapat dilihat melalui sifat dan pola respon antara pribadi, yakni 1) kecenderungan perilaku ekspresif antara lain a) sikap suka pamer dan menonjolkan diri; b) sikap suka bersaing atau berkompetisi dan tidak suka bersaing atau berkompetisi; 2) kecenderungan perilaku peran, meliputi a) sifat berkuasa dan sifat patuh; b) sifat pemberani dan pengecut secara sosial; 3) kecenderungan perilaku dalam hidup sosial, meliputi a) sifat bergaul dan tidak bergaul; b) simpatik dan tidak simpatik; c) sifat ramah dan tidak ramah (hal. 54).

Yusuf (2004) seorang anak mulai mengembangkan bentuk-bentuk tingkah laku atau perilaku sosialnya melalui pergaulan atau hubungan sosial, baik dengan 
orangtua, anggota keluarga, orang dewasa lainnya maupun teman bermainnya. Bentuk-bentuk perilaku atau tingkah laku sosial yang dimaksud sebagai berikut 1) berselisih atau bertengkar (quarreling); 2) pembangkangan (negativisme); 3) agresi (agression); 4) persaingan (rivarly); 5) menggoda (teasing); 6) kerja sama (cooperation); 7) mementingkan diri sendiri (selfishness); 8) simpati (sympaty); 9) tingkah laku berkuasa (ascendant behavior) (hal. 89).

\section{Metode}

\subsection{Jenis Penelitian}

Jenis penelitian ini adalah penelitian kualitatif, yakni mengungkap hal-hal yang berkaitan dengan fenomena, gejala sosial, dan kejadian yang berfokus pada perilaku sosial anak remaja. Penelitian ini menggunakan pendekatan fenomenalogi.

Pendekatan fenomenalogi berhubungan dengan pemahaman tentang bagaimana keseharian dunia intersubyektif (dunia kehidupan). Tujuan pendekatan fenomenalogi untuk menginterpretasikan perilaku atau tindakan sosial sekelompok orang sebagai sebuah yang bermakna (dimaknai) serta dapat merekontruksi kembali turunan makna (makna yang digunakan saat berikutnya) dari tindakan yang bermakna pada komunikasi intersubjektif individu dalam dunia kehidupan sosial. (Farid dan Adib, 2018: 67)

\subsection{Data dan Sumber Data}

Data diperoleh melalui data primer dan data sekunder. Data primer, yakni data yang langsung dari sumber aslinya, yaitu dengan menggunakan teknik observasi dan wawancara mendalam sedangkan data sekunder berasal dari dokumen di kantor Desa Waimiting.

Sumber data bersumber dari beberapa informan, yakni para remaja, tokoh masyarakat, dan masyarakat Desa Waimiting, Kecamatan Lilialy, Kabupaten Buru sedangkan untuk memperoleh data yang lengkap dan akurat, peneliti melakukan pengecekan keabsahan data dengan triangulasi sumber dan metode. Triangulasi digunakan sebagai teknik untuk mengecek keabsahan data (Moloeng, 2010: 45). Tempat yang dipilih sebagai lokasi penelitian adalah Desa Waimiting, Kabupaten Buru.

\subsection{Metode dan Teknik Pengumpulan Data}

Metode pengumpulan data dalam penelitian ini menggunakan metode observasi. Observasi merupakan studi yang disengaja dan sistematis terkait gejala-gejala psikis dan fenomena sosial dengan cara pengamatan dan pencacatan (Kartono 1980: 142). Observasi diarahkan pada kegiatan memperhatikan secara akurat dan teliti, mempertimbangkan hubungan antara aspek dalam fenomena, mencatat kejadian yang muncul, dan dilakukan dengan cara mengamati objek kajian dalam konteksnya.

Metode observasi digunakan untuk mendapatkan data lisan dan tertulis, yakni berupa perilaku sosial remaja di Desa Waimiting. Teknik-teknik yang digunakan dalam pengumpulan data, yaitu survei lapangan (field study), wawancara (interview), studi leteratur, dan studi dokumentasi. 


\subsection{Penganalisisan Data}

langkah pertama, pereduksian data, yaitu melakukan pemusatan atau pemilahan data "kasar" yang muncul dari catatan-catatan tertulis di lapangan mengenai perilaku sosial anak-anak remaja di Desa Waimiting. Langkah kedua, tahap penyajian data, yakni menyajikan data-data perilaku sosial anak-anak remaja di Desa Waimiting yang telah diperoleh dari tahap pereduksian data. Penyajian data disajikan dengan pendeskripsian yang mudah dipahami. Langkah ketiga, tahap verifikasi data, yaitu pembentukan kebenaran teori, fakta pada data perilaku sosial anak-anak remaja di Desa Waimiting yang telah dikumpulkan untuk diolah dan dianalisis agar dapat diuji secara hipotesis.

\section{Pembahasan}

Adapun pembahasan dalam penelitian mencakup dua permasalahan, yakni 1) mengidentifikasi perilaku sosial remaja di Desa Waimiting; 2) menganalisis nilainilai kearifan lokal dalam perilaku sosial remaja di Desa Waimiting. Berikut ini penjelasan tiap permasalahan di atas.

\subsection{Perilaku sosial Remaja di Desa Waimiting}

Adapun potensi pariwisata pantai Jikumerasa dapat diidentifikasi melalui potensi internal dan potensi eksternal. Berikut penjelasannya.

Pola perilaku sosial para remaja di Desa Waimiting meliputi dua ranah, yakni perilaku sosial internal (perilaku lokal) dan perilaku sosial eksternal (perilaku yang terpengaruh dari luar daerah).

\section{1) Perilaku Sosial Internal Remaja di Desa Waimiting}

Perilaku sosial internal merupakan perilaku yang berasal dari diri dan lingkungan masyarakat daerah tersebut. Perilaku internal terbentuk secara turun temurun oleh masyarakat dalam suatu daerah. Perilaku internal para remaja di Desa Waimiting terorganisir oleh pengetahuan dan pengalaman mereka selama ini, mereka selalu berusaha untuk mematuhi semua peraturan-peraturan yang telah ditetapkan oleh leluhur mereka. Banyak budaya di daerah-daerah di Kabupaten Buru yang sudah mengalami interfensi oleh budaya luar, tetapi di daerah Waimiting tidak pernah terpengaruh oleh budaya-budaya luar, masyarakat di Desa Waimiting tetap menjunjung adat dan istiadat dari leluhur mereka.

Berikut ini perilaku sosial internal remaja di Desa Waimiting:

\section{a. Persaingan}

Persaingan merupakan keinginan untuk mengungguli dan mengalahkan orang lain. Persaingan ini umumnya terlihat pada usia kanak-kanak. Selain itu, persaingan juga merupakan proses sosial suatu individu atau kelompokkelompok manusia yang bersaing mencari keuntungan melalui bidang-bidang kehidupan yang pada suatu masa tertentu menjadi pusat perhatian umum tanpa menggunakan ancaman atau kekerasan. Di kalangan para remaja Waimiting hal ini terlihat pula dalam keseharian mereka.

Persaingan di kalangan remaja di Desa Waimiting merupakan sesuatu yang wajar-wajar saja, tidak sampai menimbulkan persaingan yang berujung pertikaian atau pertengkaran. Persaingan para remaja di Desa Waimiting 
mempunyai dua tipe, yakni persaingan yang bersifat pribadi dan persaingan yang bersifat kelompok.

\section{Persaingan yang bersifat pribadi (rivarly)}

Suatu daerah yang terdiri dari sekelompok orang baik perorangan maupun suatu perkumpulan sering ada atau terjadi persaingan yang bersifat pribadi baik secara terbuka maupun secara tersembunyi (diam-diam) untuk memperebutkan kedudukan tertentu, misalnya dalam bangku sekolah setiap siswa bersaing ketat untuk meraih peringkat tertinggi dalam perolehan nilai rapor. Para remaja di Desa Waimiting melalui observasi mendalam peneliti mendapatkan fenomena yang mrenunjukkan bahwa persaingan para remaja di Desa Waimiting secara pribadi berlangsung secara sehat, sportif, dan kooperatif sehingga persaingan secara positif ini membuat diri pribadi para remaja termotivasi untuk dapat meraih prestasi semaksimal mungkin.

Munculnya perilaku sosial secara positif ini dipengaruhi oleh faktor pendidikan karakter yang di dapat dalam lingkungan keluarga dan lingkungan masyarakat.

\section{Persaingan yang bersifat kelompok}

Persaingan yang bersifat kelompok terlihat pula di kalangan para remaja di Desa Waimiting, misalnya persaingan ingin menjadi ketua dalam suatu organisasi kepemudaan (remaja masjid). Para remaja di Desa Waimiting yang terdiri dari beberapa kelompok, ketika mengadakan pemilihan ketua organisasi kepemudaan saling suportif, saling menghormati, saling menghargai sangat mereka kedepankan. Dengan perilaku sosial tersebut menunjukkan timbulnya solidaritas di antara para remaja sehingga rasa setia kawan meningkat, timbulnya sikap positif, terjadinya negosiasi di antara pihak-pihak yang bertikai.

\section{b. Kerja sama}

Manusia sebagai makhluk sosial tidak dapat dipisahkan dari suatu komunitas dan tidak ada seorang pun di dunia ini yang dapat melakukan semua kegiatan sendirian dalam memenuhi kebutuhan mereka tanpa bantuan orang lain. Kerja sama terlihat dalam perilaku para remaja di Desa Waimitng. Mereka sangat menjunjung kebersamaan dan saling tolong menolong. Adapun bentuk perilaku sosial remaja di Desa Waimiting yang tergolong dalam ranah kerja sama, yakni:

\section{Gotong royong}

Gotong royong merupakan bentuk kerja sama yang didasarkan pada kerukunan antarmanusia. Para remaja di Desa Waimiting memiliki sikap gotong royong, mereka sangat rukun dengan masyarakat. Jika ada acara pesta atau sejenisnya mereka selalu bergotong royong dengan warga kampung.

\section{Tawar menawar}

Tawar menawar merupakan salah satu bentuk kerja sama yang terkait dengan barang dan jasa dalam proses jual beli dan proses barter. Para remaja di Desa Waimiting menerapkan tawar menawar jika ingin membeli, 
menjual, atau menukar sesuatu barang kepada temannya atau kepada warga desa. Dalam proses tawar menawar, si penjual tidak memaksa si pembeli untuk membeli barang dagangannya, si penjual menawarkan secara halus barang dagangannya kepada si pembeli. Si pembeli juga tidak memaksa dalam proses menawar harga kepada si penjual. Hal ini dilakukan agar si penjual dan si pembeli sama-sama merasa nyaman.

\section{c. Simpati}

Simpati tampak pula pada perilaku para remaja di Desa Waimiting. Mereka mempunyai rasa simpati terhadap sesama baik itu yang berasal dari desa Waimiting sendiri atau yang berada di luar daerah mereka. Rasa bersimpati ini sudah tertanam dari sedini mungkin, mereka dibekali oleh orangtua mereka untuk selalu menyayangi, menghargai, mengayomi orang lain. Sehingga hal ini terlihat pula saat mereka berkomunikasi, tutur bahasa mereka sangat lembut.

\section{d. Empati}

Empati adalah keadaan mental yang membuat seseorang merasa atau mengidentifikasi dirinya dalam keadaan perasaan atau pikiran yang sama dengan orang atau kelompok lain. Mereka mempunyai rasa empati terhadap orang lain dan menjadikan orang lain sebagai seseorang yang sangat dihargai dan dihormati. Mereka juga selalu berempati terhadap orang yang dirundung kekusahan dan kemalangan.

e. Membagi

Membagi merupakan sikap positif untuk memperoleh persetujuan sosial dan diterimanya di lingkungan sosial. Sikap membagi para remaja di Desa Waimiting tampak ketika mereka mempunyai sesuatu, mereka selalu membagikannya kepada teman-teman mereka yang lain. Hal ini menunjukkan adanya identitas keakraban dan senasib sepenanggungan.

\section{f. Meniru}

Sikap meniru merupakan mencontohi suatu perilaku orang lain yang dianggapnya positif. Sikap ini tampak pada para remaja di Desa Waimiting. Mereka saling meniru pada gaya hidup, prestasi, dan sebagainya.

\section{g. Nasionalis}

Nasionalis merupakan sikap cinta dan menjunjung tinggi integritas daerah sendiri. Para remaja di Desa Waimiting sangat menghargai dan mencintai daerah mereka. Hal ini terlihat ketika mereka tidak pernah melanggar petuah-petuah yang telah ditetapkan oleh para leluhur mereka. Meskipun mereka sering berbaur dengan orang-orang yang berasal dari luar daerah mereka, tetap mereka sangat kokoh pendiriannya dalam menjunjung adat dan budaya yang mereka miliki.

h. Patuh

Patuh adalah sikap suka menurut perintah atau aturan yang telah ditetapkan. Kepatuhan para remaja di Desa Waimiting terlihat ketika mereka sangat mematuhi peraturan yang berlaku di Desa Waimiting. peraturan 
tersebut ditetapkan oleh para leluhur mereka. Kepatuhan para remaja ini terbentuk sejak mereka masih kanak-kanak.

i. Cinta lingkungan

Cinta lingkungan merupakan kecintaaan seseorang terhadap alam sekitarnya. Sikap cinta lingkungan ini tampak pada para remaja di Desa Waimiting yang tidak membuang hajat atau kotoran di tanah atau di lingkungan mereka. Jika mereka akan membuang hajat maka harus pergi ke pantai. Peraturan ini sudah ditetapkan oleh leluhur mereka.

2) Perilaku Sosial Eksternal Remaja di Desa Waimiting

Perilaku sosial eksternal remaja di Desa Waimiting merupakan perilaku yang berasal dari luar lingkungan mereka. Artinya, akibat intensitas kebersamaan para remaja dengan teman-temannya di luar desa Waimiting sedikit berpengaruh pada pola pikir mereka, dari pola pikir tersebut mengakibatkan berubah pula perilaku sosial mereka.

Perilaku ekternal ini muncul dalam diri ribadi para remaja ketika mereka sangat rutin berbaur dengan teman-temannya yang berasal dari luar desa Waimiting.

Berikut ini perilaku sosial eksternal remaja di Desa Waimiting:

a. Lebih banyak menghabiskan waktu dengan Gedget

Perilaku remaja di Desa Waimiting mengalami interfensi perilaku sosial dari luar, yakni lebih banyak menghabiskan waktu dengan handphone mereka. Hal ini, menimbulkan suatu permasalahan di lingkungan keluarga dan dalam perkumpulan mereka. Dahulu sebelum adanya handphone kebersamaan seorang anak dengan orangtuanya sangat intens dan jika mereka punya masalah selalu dibicarakan baik-baik dengan orangtua mereka, tetapi sekarang hal ini sudah jarang ditemukan.

b. Sikap egois

Perilaku sosial para remaja di Desa Waimiting mengalami interfensi perilaku sosial dari luar, yakni sikap egois. Sikap egois para remaja ini dalam bentuk ingin menang sendiri, merasa argumennya paling benar karena mereka sudah mendapatkan ilmu yang luas dibanding yang lain. Namun, sikap egois mereka ini tidak sampai pada penolakan terhadap aturan atau pantang larang yang telah ditetapkan oleh leluhur mereka.

c. Kurang bersosialisasi

Akibat dari sering bergaulnya dengan remaja di luar desa Waimiting menjadikan para remaja berjiwa kurang bersosialisasi dengan masyarakat. Namun, hal ini hanya kadang-kadang saja ditemukan pada beberapa remaja.

d. Cenderung bebas dalam menampilkan diri

Perilaku ini sering terlihat pula di kalangan remaja di Desa Waimiting. Mereka ingin terlihat agresif saat mengemukakan suatu argumen baik itu pada saat pertemuan atau musyawarah. 


\subsection{Nilai-Nilai Kearifan Lokal dalam Perilaku Sosial Remaja di Desa Waimiting}

Kearifan lokal dalam perilaku sosial remaja di Desa Waimiting berasal dari lingkungan yang terikat dengan adat istiadat, pikiran positif manusia terhadap alam sekitar, kegiatan yang dilandasi oleh nilai agama, nilai pendidikan, dan nilai sosial, adanya petuah-petuah dari nenek moyang yang sudah terbentuk lama dalam masyarakat, pantang larang yang berlaku dalam masyarakat. Berbagai sumber kearifan lokal yang telah dijelaskan sebelumnya terkandung nilai-nilai yang mencerminkan kearifan lokal perilaku sosial remaja di Desa Waimiting. Beikut ini penjelasnnya.

\section{1) Adat Istiadat}

Adat istiadat merupakan suatu perbuatan yang dilakukan secara berulangulang dan sudah menjadi suatu kebiasaan yang tetap atau statis dan dihormati oleh masyarakat. Di Desa Waimiting ada berbagai jenis adat istiadat yang harus dijunjung oleh masyarakat seperti larangan mengadakan acara joget, larangan membangun toilet di dalam rumah, dilarang membuang hajat di darat (di tanah).

Dari identifikasi berbagai jenis kearifan lokal yang tampak dalam adat istiadat maka nilai-nilai kearifan lokal tersebut berpengaruh terhadap perilaku sosial para remaja di Desa Waimiting, antara lain:

\section{a. Nilai kepatuhan}

Kepatuhan merupakan suatu bentuk sikap atau perilaku manusia yang taat pada aturan atau perintah yang sudah ditetapkan oleh tetuah adat atau secara resmi oleh pemerintah yang di dalamnya terbentuk secara prosedural.

Perilaku patuh para remaja di Desa Waimiting tampak ketika para remaja tidak melanggar hukum atau aturan yang berlaku dalam lingkungan tersebut. Para remaja sangat meyakini larangan-larangan yang telah ditetapkan oleh nenek moyang mereka. Misalnya, ketika ada acara pernikahan tidak diperbolehkan untuk mengadakan acara joget atau acara hura-hura tetapi mereka mengadakan acara menari yang biasa disebut tari sawat buru dan gambus. Peraturan ini bagi para remaja di Desa Waimiting sangat positif. Para remaja sudah terbiasa karena turun temurun larangan ini sudah ada.

Selain itu, para remaja juga patuh terhadap larangan untuk tidak meminum-minuman keras dan berjudi di lingkungan masyarakat. Para remaja yakini bahwa jika melanggar larangan para leluhur akan mendatangkan malapetaka atau bala di kampung tersebut.

Kepatuhan juga terlihat ketika para remaja menjunjung tinggi larangan untuk tidak membangun jamban di rumah-rumah warga serta larangan membuang hajat di tanah. Masyarakat di Desa Waimiting diwajibkan membuang hajat di pantai. Masyarakat di Desa Waimiting mempunyai falsafah terkait larangan ini, yakni manusia tercipta dari tanah, jika kita membuang hajat di tanah berarti sama saja kita mengotori tubuh kita sendiri.

\section{b. Kebersamaan}

Kebersamaan adalah sebuah ikatan yang terbentuk karena adanya rasa persaudaraan atau kekeluargaan. Kebersamaan yang terlihat dari perilaku 
sosial para remaja di Desa Waimiting ketika adanya kerja bakti, adanya masyarakat yang mengadakan pesta, adanya kedukaan. Kebersamaan para remaja ini menunjukkan eksistensi sikap positif dan mudah peka terhadap situasi sosial di Desa Waimiting.

Para remaja berbondong-bondong membantu segala macam kegiatan yang ada di masyarakat.

c. Nilai Pendidikan

Nilai pendidikan adalah sesuatu yang diyakini kebenarannya dan mendorong orang untuk berbuat positif di dalam kehidupan baik secara individu maupun kelompok. Nilai-nilai pendidikan adalah nilai yang mengajarkan anak-anak atau generasi muda memperbaiki diri dan meningkatkan kualitas dirinya (Mansyur, 2020:278). Nilai pendidikan dalam perilaku sosial para remaja di Desa Waimiting sudah terwujud saat mereka masih kecil. Didikan dari orangtua mereka membuat para remaja mengetahui apa yang mesti dilakukan atau ditaati dan mana yang mesti dihindari. Pendidikan tentang adat istiadat sangat dijunjung sebelum pendidikan secara formal di bangku sekolah.

\section{d. Saling menghormati}

Saling menghormati merupakan sikap timbal balik dari sekelompok orang yang saling memahami dan memberikan toleransi (Susiati: 56). Perilaku sosial remaja di Desa Waimiting tampak saat mereka bertemu dengan para orang tua mereka menunduk atau tabe memberi salam.

Selain itu, para remaja juga menghormati semua keputusan tetuah adat. Para remaja di Desa Waimiting tidak pernah menginterfensi ketetapan yang dikeluarkan oleh para tetuah adat meskipun mereka cenderung berbaur dengan masyarakat yang di luar Desa Waimiting tetapi ketika para remaja masuk dalam perkampungan mereka tetap menghormati adat dan budaya mereka.

\section{2) Sikap Positif Terhadap Lingkungan/Alam}

Sikap positif terhadap lingkungan merupakan suatu sikap cinta dan menjaga lingkungan dari kerusakan oleh manusia. Sikap positif terhadap lingkungan pada perilaku sosial para remaja di Desa Waimiting terlihat ketika masyarakat, khususnya para remaja mentaati dan menghormati larangan yang mereka yakini untuk tidak membuang hajat di darat atau di tanah. Dari sikap menghargai dan menghormati tersebut muncul nilai cinta dan nilai patuh para remaja terhadap peraturan atau larangan yang telah ditetapkan oleh leluhur mereka.

3) Kegiatan Masyarakat yang Dilandasi oleh Aspek Keagamaan, Pendidikan, dan Sosial Budaya.

Lingkungan masyarakat di Desa Waimiting sangat dilandasi oleh ilmu keagamaan, pendidikan, dan sosial budaya. Hal ini terlihat pula pada perilaku sosial para remaja di Desa Waimiting yang menghormati dan menjunjung tinggi nilai-nilai yang terdapat dalam ketiga aspek, yakni agama, pendidikan, dan sosial budaya. Adapun nilai-nilai dari ketiga aspek yang dimaksud adalah:

a. Berkeyakinan 
Berkeyakinan adalah seseorang atau sekelompok orang yang memiliki keyakinan atau kepercayaan terhadap sesuatu yang dianggap benar-benar ada (Susiati, 2019: 58). Dalam aspek agama terdapat beberapa bentuk kearifan lokal di Desa Waimiting, yakni kegiatan Isra Mi'raj, Maulid Nabi Saw, dan tahlilan pada hari ketiga, ketujuh, dan kesembilan orang yang telah meninggal. Dari beberapa bentuk kearifan lokal tersebut secara tidak langsung membentuk suatu pola kepercayaan para remaja untuk berkeyakinan bahwa dengan kegiatan-kegiatan tersebut memunculkan rasa keakraban dalam masyarakat, khususnya pada kalangan remaja.

Selain itu, para remaja juga berkeyakinan bahwa jika membuang hajat atau kotoran di darat (tanah pekarangan) sama saja mengotori badan atau tubuh kita sendiri. Jika melanggar ketentuan yang sudah ditetapkan oleh leluhur maka suatu saat akan datang bala atau musibah besar.

\section{b. Tanggung jawab}

Tanggung jawab merupakan kesadaran manusia akan tingkah laku atau perbuatan yang disengaja maupun tidak disengaja (Susiati, 2019: 57). Dalam peribahasa ada ungkapan bahwa seseorang hendaknya bertanggungjawab atas apapun yang dia lakukan (Mansyur, 2020:261). Perilaku tanggung jawab para remaja di Desa Waimiting terlihat ketika adanya acara atau kegiatan yang dilaksanakan baik itu secara individu maupun kelompok. Para remaja bahu-membahu membantu karena bagi mereka, jika ada kegiatan dalam masyarakat, itu merupakan tanggung jawab bersama.

\section{c. Saling membantu dan kerja sama}

Kearifan lokal yang terdapat di Desa Waimiting tampak pula pada budaya masaurat. Masaurat merupakan bentuk acara yang di dalamnya ada pemberian bantuan berupa sejumlah uang dari sanak saudara kepada keluarga mereka yang ingin melangsungkan pernikahan atau melanjutkan pendidikan. Saling membantu dan kerja sama terlihat pada budaya masaurat tersebut sehingga para remaja di Desa Waimiting juga ikut membantu jika ada keluarga mereka yang membutuhkan bantuan.

4) Petuah-petuah Leluhur

Petuah leluhur merupakan nasihat para leluhur yang mengandung kebaikan dan dipercaya dapat membawa kepada kemashlahatan dan kemakmuran. Petuahpetuah para leluhur di Desa Waimiting sudah berakar dan menjadi guru besar bagi masyarakat Waimiting. Adapun petuah-petuah tersebut mencakup, a) tidak diperbolehkan mendirikan jamban di dalam atau dipekarangan rumah; b) tidak diperbolehkan membuang hajat di lingkungan atau di daratan Waimiting; c) tidak diperbolehkan meminum-minuman keras dan berjudi; d) tidak diperbolehkan mengadakan acara joget dan berjoget.

Semua petuah-petuah leluhur di atas sangat dihormati oleh masyarakat Waimiting, khusunya para remajanya. Para remaja meyakini bahwa semua petuah-petuah tersebut dapat mejadikan mereka manusia yang beradab, terdidik, dan berbudaya.

Nilai-nilai kearifan lokal dalam perilaku sosial para remaja di Desa Waimiting, yakni kepatuhan, kebersamaan, nilai pendidikan, saling menghormati, cinta, 
berkeyakinan, tanggung jawab, dan saling membantu serta kerja sama. Dari beberapa nilai kearifan lokal di atas teridentifikasi ada beberapa nilai yang sudah bergeser di kalangan para remaja di Desa Waimiting, yakni.

\section{a. Memudarnya nilai kebersamaan}

Memudarnya nilai kebersamaan di antara para remaja terlihat ketika mereka sudah tidak terlalu proaktif dalam kegiatan-kegiatan di masyarakat. Hal ini disebabkan oleh para remaja di Desa Waimiting lebih aktif dalam mengurus pendidikan yang mereka jalani. Dari kesibukan mereka itu berimplikasi terhadap rendahnya kebersamaan mereka dengan para masyarakat.

\section{b. Memudarnya nilai kerja sama}

Nilai kerja sama terlihat telah memudar dari kalangan para remaja di Desa Waimitng. Hal ini disebabkan oleh kesibukan para remaja dengan kegiatan-kegiatan di luar desa Waimiting.

\section{Penutup}

Berdasarkan hasil penelitian dalam pembahasan sebelumnya, dapat disimpulkan beberapa hal yang menjadi temuan dalam penelitian ini terkait perilaku sosial remaja di Desa Waimiting dan nilai-nilai kearifan lokal yang bergeser dalam perilaku sosial remaja di Desa Waimiting.

Perilaku sosial remaja di Desa Waimiting terbagi atas dua, yakni 1) perilaku sosial internal remaja di Desa Waimiting yang meliputi persaingan (persaingan yang bersifat pribadi dan persaingan yang bersifat kelompok), kerja sama (gotong royong dan tawar menawar), simpati, empati, membagi, meniru, nasionalis, patuh, dan cinta lingkungan; 2) perilaku sosial ekternal remaja di Desa Waimiting, antara lain lebih banyak menghabiskan waktu dengan gedget, sikap egois, kurang bersosialisasi, cenderung bebas dalam menampilkan diri.

Nilai-nilai kearifan lokal dalam perilaku sosial remaja di Desa Waimiting, yakni dilihat dari wujud adat istiadat nilai kearifan lokal meliputi kepatuhan, kebersamaan, nilai pendidikan, saling menghormati; dilihat dari wujud sikap positif terhadap limgkungan atau alam, antara lain cinta dan saling menghargai; wujud kegiatan masyarakat yang dilandasi oleh aspek keagamaan, pendidikan, dan sosial budaya, yakni berkeyakinan, tanggung jawab, dan saling membantu serta kerja sama. Nilai-nilai kearifan lokal yang bergeser dalam perilaku sosial remaja di Desa Waimiting, yakni nilai kebersamaan dan nilai kerja sama.

Hasil penelitian ini diharapkan dapat memberikan wawasan mengenai adat istiadat yang telah arif di tengah-tengah masyarakat sehingga pemerintah dengan segenap masyarakat khusunya masyarakat Desa Waimiting dapat dan terus menjaga tradisi yang telah turun temurun oleh Dato Leluhur mereka. Bagi perkembangan keilmuan khususnya dalam bidang budaya, dengan hasil penelitian ini dapat menjadi tonggak ilmu pengetahuan terbaru yang memberikan gambaran unik dan berbeda terkait kearifan lokal suatu masyarakat di Kabupaten Buru.

\section{Ucapan Terimakasih}

Ucapan terima kasih penulis ucapkan kepada pengelola Jurnal SANG PENCERAH atas diterimanya artikel ini untuk dipublikasi. Penulis juga 
mengucapkan terima kasih kepada Kemenristekdikti dan LLDikti Wilayah XII Maluku dan Maluku Utara atas kepercayaannya memberikan dana hibah terhadap penelitian ini. Selanjutnya, ucapan terima kasih penulis ucapkan kepada Ketua Yayasan Muslim Buru, Rektor Universitas Buru, dan LPPM Universitas Iqra Buru atas dukungan sehingga penelitian ini dapat selesai tepat waktu.

\section{Daftar Pustaka}

Abdulsyani. (2015). Sosiologi Skematika, Teori, dan Terapan (Edisi Revisi). Jakarta: PT Bumi Aksara.

Aslan. (2017). Nilai-nilai Kearifan Lokal Dalam Buaya Pantang Larang Suku Melayu Sambas. Jurnal IImu Usbuluddin. 16(1), 11-20.

Farid, M., \& Moh. Adib. (2018). Fenomenologi: Dalam Penelitian IImu Sosial. Jakarta: Prenada Media

Hasbullah. (2012). Rewang: Kearifan Lokal dalam Membangun Solidaritas dan Integrasi SosialMasyarakat di Desa Bukit Batu Kabupaten Bengkalis. Jurnal Sosial Budaya, 9(2), 41-53

Hilmi, M. Z. (2015). Nilai-nilai Kearifan Lokal Dalam Perilaku Anak Remaja Di Desa Sepit Kecamatan Keruak Kabupaten Lombok Timur. Journal of Educational Social Studies, 4(2), 87-100.

Kartono, K. (1980). Pengantar Metodologi Research Sosial. Bandung: Alumni.

Mansyur, F. A. (2016). Onina Manga Mancuana Mangenge: Cultural Values of Wolio People that Never Fade (A Study of Anthropological Linguistics). Proceeding International Prasasti III: Current Research in Linguistics. Surakarta: Linguistics Postgraduate Program of Universitas Sebelas Maret. DOI: https://doi.org/10.20961/pras.v0i0.1526.

Mansyur, F. A. (2018). Onina Manga Mancuana Mangenge: Ungkapan Tradisional Orang Wolio. Disertasi. Yogyakarta: Pascasarjana FIB UGM.

Mansyur, F. A. \& Ratna S. (2020). A Cognitive Semantics Analysis of Wolio Proverbs Related to the Human Body. Advances in Social Science, Education and Humanities Research, volume 436, Published by Atlantis Press SARL. Retrieved from https://www.atlantis-press.com/proceedings/bis-hess19/articles.

Mansyur, F. A. \& Suherman, L. O. A. (2020). The Function of Proverbs as Educational Media: Anthropological Linguistics on Wolio Proverbs. ELS Journal on Interdisciplinary Studies in Humanities, 3 (2), 271-286. DOI: 10.34050/elsjish.v3i2.10505.

Martin, G., \& Pear, J. (2015). Modifikasi Perilaku dan Penerapannya, Terjemahan dari Behavior Modification oleh Yudi Santoso. Yogyakarta: Pustaka Pelajar.

Moleong, L. (2010). Metodologi Penelitian Kualitatif. Bandung: Remaja Rosdakarya.

Ridwan, N. A. (2007). Landasan Keilmuan Kearifaan Lokal. Puwokerto: STAIN.

Ritzer, G. (2014). Teori Sosiologi Modern. Terjemahan. Jakarta: Kencana Prenadamedia Group. 
Singsomboon, T. (2014). Tourism Promotion and The Use of Local Wisdom Through Creative Tourism Process. International Journal of Business Tourism and Applied, 2(2), 32-37.

Sukmayadi, T. (2018). Nilai-nilai Kearifan Lokal dalam Pandangan Hidup Masyarakat Adat Kampung Kuta. Jurnal Pancasila dan Kewarganegaraaan, 3(1), 19-29.

Susiati, S. (2018). Nilai Budaya Suku Bajo Sampela Dalam Film The Mirror Never Lies Karya Kamila Andini [The Cultural Values of The Bajo Sampela Ethnic Group in The Mirror Never Lies Film by Kamila Andini]. Jurnal Totobuang, 6(2), 297,311.

Susiati, \& Taufik. (2019). Nilai Pembentuk Karakter Masyarakat Wakatobi Melalui Kabhanti Wa Leja. Jurnal Totobuang, 7(1), 117-137.

Tarakanita, I., \& Cahyono, M.Y.M. (2013). Komitmen Identitas Etnik dalam Kaitannya dengan Eksistensi Budaya Lokal. Jurnal Zenit, 2(2), 1-14.

Yusuf, S. (2004). Psikologi Perkembangan Anak dan Remaja. Bandung: PT Remaja Rosdakarya. 